\title{
AN ALBINO BARN SWALLOW AND TWO ALBINO HOUSE SPARROWS
}

\author{
by WILLIAM J. MAHER*
}

The purpose of this note is to escribe an almost pure white juvenile arn Swallow from Mozart, Saskathewan, and to record a pale juvenile ouse Sparrow from Saskatoon and an bino House Sparrow at Langham.

Albinism is a conspicuous plumage onormality of birds, usually of enetic origin, and albino individuals ways excite interest. A true albino cks all skin pigment and hence has white feathers and pale horn-coloured bill and claws. The bill, feet and eyes appear pink from underlying blood vessels. Many albinos have some traces of pigment and such individuals are more accurately termed pale or leucistic. Their colour can range from almost true albinism to a slightly pale version of the species' normal colour.

A pale Barn Swallow was sent to me by A. W. Cottam of Mozart on August 28,1973 . The bird was seen alone flying weakly and finally settled on a man's hand. It died shortly afterwards.

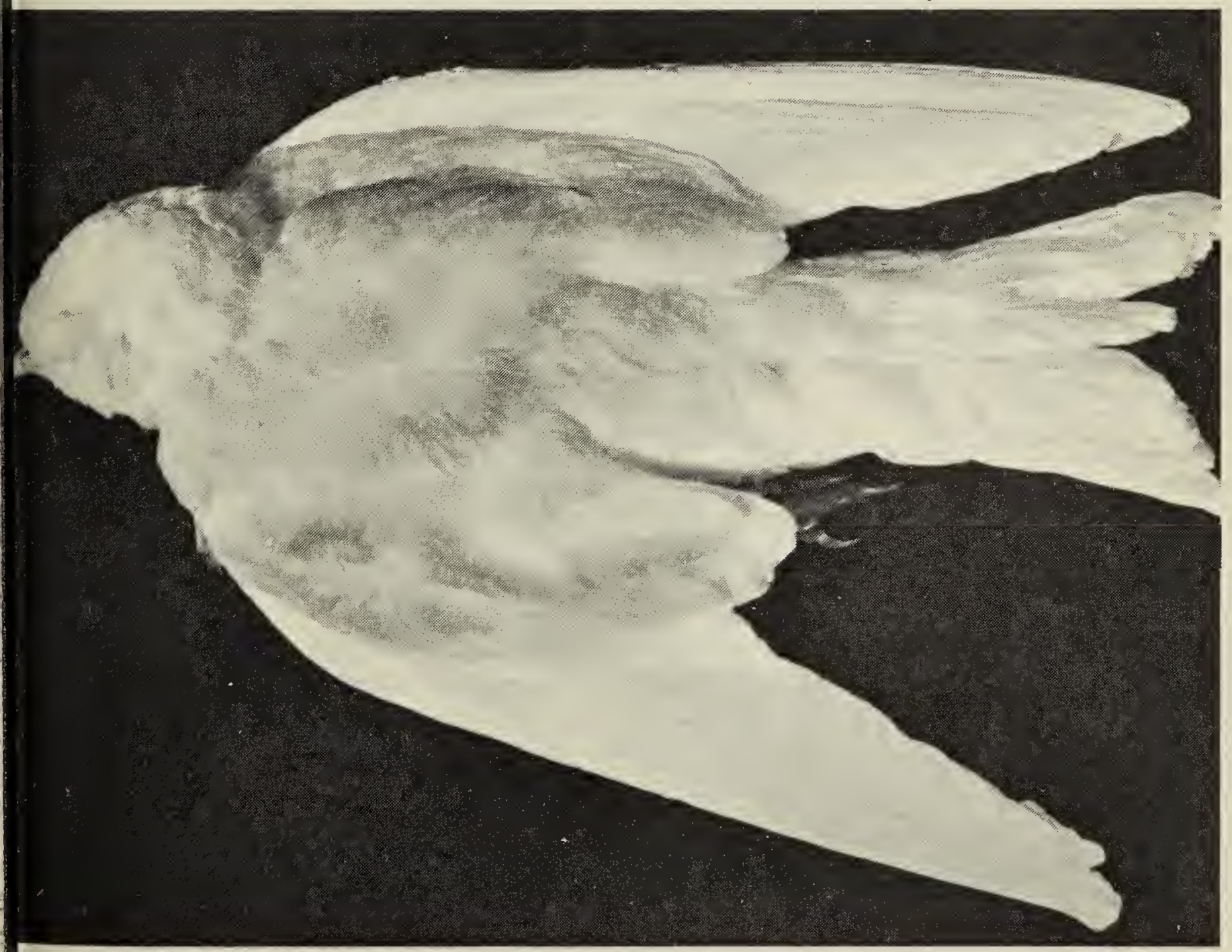

Ibino Barn Swallow. 
The bird is a juvenile, with the swollen, yellow corners of the mouth typical of nestlings. Its small size (wing $97.4 \mathrm{~mm}$; tail $47.3 \mathrm{~mm}$ ) suggests that it had recently fledged. It weighed only 11.6 grams.

The specimen (see photo) appears to be pure white; but closer inspection discloses that it is not. The areas which are cinnamon coloured on a normal Barn Swallow, the undersides, throat and forehead, are indeed pure white. All of the back behind the forehead, the wing and tail feathers, which are normally blue-black, are tinted tan or cinnamon. This pigment is unevenly distributed, the scapular (shoulder) feathers and wing coverts being darkest. Pigmentation in primaries and secondaries is light and is darker near the base of the vanes than peripherally. The tail feathers are also pale tan. The white tail spots of the normal swallow are evident but do not show in the photograph. The bill, tarsus and feet lack pigment and the pupil of the eye is pink but there is some dark pigment in the eyeball.

A pale juvenile House Sparrow was seen at about the same time that the Barn Swallow was received. It was in a large flock of juvenile sparrows on the University of Saskatchewan, Saskatoon Campus, on September 2. This bird was also not a true albino but was generally light in colour.

A completely albino House Sparrow was obtained from Langham in midNovember. It appears to be an adult. At least 29 records of albino or partly albino birds have been published in the Blue Jay (Table 1). There are 18 species in the list; 14 of them represented only once. Four species account for half of the records. They are the Robin, House Sparrow and Barn Swallow, with four records each, and the Crow with three records.

A. O. Gross'2 analysed 1,847 records of albino birds in North
America. His records show that, as the records above, albinos are muc more frequently reported in som groups than in others. The Hous Sparrow with 104 records $(5.5 \%$ total records) was second only to th American Robin with 152 record Albinisim is also common in the Bar Swallow as indicated by 25 recor ( $1.4 \%$ of total records) of albino in dividuals. Thus, albino birds appear $t$ be recorded on the prairies in roughl the same proportions as in all of Nort America.

Some of the records from th prairies are interesting for othe reasons. Albino or partly albino ir dividuals are readily noticed and it dividually recognizable and some hav been seen for more than one seasol They thus provide some interesting ir formation on how long birds live in th wild. A partial albino male Rer winged Blackbird was seen nea Regina for 5 successive seasons. ${ }^{1.5}$ partly albino female House Sparro nested for at least 5 seasons Nipawin ${ }^{27}$ and a partly albino fema Mallard nested at Waterhen Mars near Kinistino for 2 seasons. ${ }^{3}$

In almost all birds pigments ar either melanins which produce black brown, dull red and dull yello colours, or carotenoids which produc red, orange and yellow colours. Albinism usually involves onl melanin pigments. Albinism involvin carotenoids is rare but does occur. ${ }^{13}$ a bird has both types of pigmen albinism will usually involve only th loss of the melanin pigments and th carotenoids are retained - thus th albino Yellow-headed Blackbird an the redpoll reported above retaine their yellow and pink pigments resper tively. ${ }^{*}$ it The Common Crackl record $^{7}$ is also interesting because th description of the specimen indicate that, as with the Barn Swallow repor ted here, the normally blue-blac 
idescent plumage of the grackle had me pigment. Thus, it was an incomlete albino.

able 1 - Records of albino or partly albino birds in the Blue Jay

$\begin{array}{llc}\text { pecies } & \begin{array}{l}\text { No. of } \\ \text { records }\end{array} & \text { Reference } \\ \text { anada Goose } & 1 & 19 \\ \text { allard } & 1 & 3 \\ \text { reen-winged Teal } & 1 & 20 \\ \text { larp-t. Grouse } & 1 & 6 \\ \text { andhill Crane } & 1 & 18 \\ \text { ree Swallow } & 1 & 1 \\ \text { arn Swallow } & 4 & 2,5,17,28 \\ \text { lack-b. Magpie } & 1 & 31 \\ \text { ommon Crow } & 3 & 11,24,25 \\ \text { ouse Wren } & 1 & 22 \\ \text { merican Robin } & 4 & 5,9,16,23 \\ \text { ch. Waxwing } & 1 & 21 \\ \text { ouse Sparrow } & 4 & 4,26,27,30 \\ \text { ellow-head Blkbd } & 1 & 8 \\ \text { ed-winged Blkbd } & 1 & 15 \\ \text { rewer's Blkbd } & 1 & 10 \\ \text { ommon Grackle } & 1 & 7 \\ \text { edpoll } & 1 & 14\end{array}$

OTAL 18 species 29 records

NERILL. Mrs. E. 1955. Nature notes from Crocus. Blue Jay 13(1):7.

IRD, D. 1944. Bird notes. Blue Jay 2(2): 11.

RACE, R. K. 1972. Alhino Mallard nests at Waterhen marsh. Blue Jay 30(2):95.

READNER, J. 1958. Albino sparrow. Blue Jay $16(1): 31$

UCEUK, Mrs. W. 1950. Albino robin. Blue Jay $8(3): 14$.

OATES, C. R. 1947. Shurp-tailed Grouse'. Blue Jay $5(3): 31$
'DEW, J., and D. SHUBA. 1960. White hlackbirds at Regina. Blue Jay 18(2):74-75.

'DEMIANYK, J. W. 1972. Albino Yellow-leaded Blackbird. Blue Jay 30(2): 129.

"DOWNING, Mrs. H. 1944. Rohin. Blue Jay 3(4):34. (also 4(2):15).

"FOREMAN, Mrs. J. R. 1942. An albino blackbird. Blue Jay I(1):3.

'GREENBANK, J. D. 1953. Interesting glimpses of nature. Blue Jay $11(2): 8$.

1:GROSS, A. O. 1965. The inciden 'e of al hinism in Nortl Ainerican birds. Bird-Banding 36(2):6771 .

1:HARRISON, G. J. O. 1963. Non-meleanic, carotenistic and allied variant plarnages in birds. Brit. Ornith. Club. Bull. 83: 90-96.

'JORDHEIM, S. O. 1972. Alhino relpoll. Blue Jay $30(2): 135$.

1.5EDINGHAM, G. F. 1963. Partial albino redwing sighted for fifth year. Blue Jay 21 (3): 105.

1'LEE, N. 1972. Albino rohin at Selkirk, Manitoba. Blue Jay $30(2): 131$.

'LYYSTER, B. 1961. An albino swallow: Blue Jay 19(2):94.

"MILLER, R. S. 1961. A partial albino Sandhill Crane. Blue lay 19(3):112.

"MORGOTCH, L. A. 1966. A partial albino Canada Goose. Blue Jay 24(4):201.

"NERO, R. W. 1963. Imperfect albinism in a Green-winged Teal. Blue Jay 21(1):6.

"PIKE, C. D. 1965. Albino Bohernian Waxwing. Blue Jay 23(2): 108.

-PYI.YPEC, B. 1962. The House Wren and their albino. Blue Jay 20(4): 170.

${ }^{2}$ REPCHINSKI, A. 1958. You were asking. Blue Jay $16(4): 185$.

$\because$ SCHAEFER, C. 1943. Albino crow. Blue Jay $6(3): 9$.

2.SEALY, S. 1967. Record of white-harring in Common Crow. Blue Jay 25(3):121

${ }^{24}$ SOUTHEY, C. F. 1954. An alhino sparrow. Blue Jay $12(4): 5$.

${ }^{27}$ STR EET, M. G. 1947. English Sparrow. Blue Jay $5(3): 31$

${ }^{2}$ UNDER WOOD, K. 1960. The alhino swallow. Blue Jay 18(4): 175.

2:"VAN TYNE, J., and A. J. BERGER. 1959. Fundamentals of ornithology. John Wiley and Sons: New York. 624 pp.

"WARD, A. 1955. The unwelcome albino. Blue Jay 13(2): 15 .

"WOLTERS, Mrs. O. L. 1950. An alhino inagpie. Blue Jay $8(1): 9$.

MOOSE is an American Indian word, from mus, as spoken by the assamaquoddy tribe, and moos, as spoken by the Massachuset tribe. The word heans "he strips, eats off," and specifically refers to the eating habits of the 1oose. Mary Durant. In Pursuit of the Mous, the Snaile and the Clamm. 